\title{
ECONOMIC AND ENERGY EFFICIENCY OF BACTOPASLON APPLICATION IN THE TECHNOLOGY OF POTATO CULTIVATION
}

\author{
Khalep Yu. M., Kozar S. F., Yevtushenko T. A. \\ Institute of Agricultural Microbiology and Agricultural Production NAAS \\ 97, Shevchenko str., Chernihiv, 14027, Ukraine \\ E-mail: tatianazherebor@rambler.ru
}

The paper describes the investigation results of economic and energy efficiency of microbial preparation Bactopaslon application in the technology of potato cultivation. The high efficiency of the studied biological product due to the advanced yield increase rates as compared to the increased costs was established.

Keywords: potato, Bactopaslon, economic efficiency, energy efficiency.

Application of microbial preparations into the modern crop production technologies is an effective mean for environmentally friendly crops yield enhancement. As the results of our previous research an experimental microbial preparation Bactopaslon, with Azotobacter bacteria activated with the potato lectin as bio-agents, was created. The high efficiency of this preparation was proven on potato [1]. It should be noted, that economic efficiency is one of the most important criteria for product evaluation, especially in case of such innovative product as Bactopaslon. For developers of microbial preparations such information is necessary to evaluate product competitiveness on the market of innovative research for agriculture in order to identify the most promising product, while for the consumer (agricultural management) - to determine the appropriateness of its application.

To this end, we investigated the economic effects of pre-planting potato bacterization with Bactopaslon.

Materials and methods. Evaluations were made using the average values of potato yields of Fantasia variety obtained during three-year field experiments on the meadow black leached light loam soils in Institute of Agricultural Microbiology and Agricultural Production NAAS. Experimental conditions were described in our previous research work [1]. Estimation of economic efficiency of potato bacterization was performed according to the recommendations based on the method of results comparison of certain agricultural technique and the cost of its introduction, using such indicators of economic efficiency as cost per unit of output, profits per 1.0 tons of product and per 1.0 ha of cultivation area, its production and additional costs profitability $[2,3]$.

Technological operations, resource consumption and prices are taken from the standards of National Scientific Centre "Institute of Agricultural Economics NAAS" (Kyiv) with the exception of additional direct and overhead costs associated with the use of the studied microbial preparation $[4,5]$.

Estimation of yield and cost changes impact per 1 hectare on the deviation of cost of 1 ton of potatoes in the experiment was compared to the control values using the following two-factor deterministic model: 


$$
\mathrm{C}=\frac{\mathrm{B}}{\mathrm{y}}
$$

where $\mathrm{C}$ - cost of 1 ton of potatoes, UAH

$\mathrm{B}$ - expenditures per 1 ha of planting $\mathrm{UAH}$

$\mathrm{Y}$ - potato yield, $\mathrm{t} / \mathrm{ha}$.

The quantitative effect of changes of potatoes yield and costs per 1 ha of planting on the deviation of the profit per 1 ton of potatoes was determined by the following three-factor deterministic model:

$$
\Pi \mathrm{T}=Ц-\frac{\mathrm{B}}{\mathrm{y}},
$$

where Пт - profit per 1 ton of product, UAH

$Ц-$ sale price of 1 ton of potatoes, UAH

To determine the quantitative impact of changes in yield and size of the monetary costs per 1 ha of cultivated crops on profit deviation per 1 ha of planting three-factor deterministic model was used:

$$
\text { Пга }=\text { Ц } \times \text { У }-\mathrm{B},
$$

where Пга - profit per 1 ha of planting, UAH

The quantitative effect of changes of studied factors on the deflection of profitability of potato production was determined by the following deterministic model:

$$
\mathrm{P}=\left(\frac{Ц \times \mathrm{Y}}{\mathrm{B}}-1\right) \times 100,
$$

where $\mathrm{P}$ - profitability of potato production, $\%$.

This model is obtained from the traditional economic profitability model in order to isolate the effect of studied factors:

$$
\mathrm{P}=\frac{\Pi}{\mathrm{B}} \times 100 \%=\frac{(Ц \times \mathrm{Y})-\mathrm{B}}{\mathrm{B}} \times 100 \%=\left(\frac{Ц \times \mathrm{V}}{\mathrm{B}}-1\right) \times 100 \%
$$

Results and discussions. Parameters directly related to bacterization (direct costs: cost of preparation, treatment, transportation and sorting of additional yield) together with the changes in overhead expenses, that at calculation of production costs are allocated proportionally to direct ones were taking into the account in order to determine the costs associated with the use of biological preparations.

For this purpose, the full production cost was calculated, since the income, which is primarily of the main interest to the product consumer is the difference 
between the price and the full cost of production. Such methodological and methodical approach in cost estimation slightly increase the cost of biological preparation, but at the same time, it promotes precise assessment of its costeffectiveness. The calculation results of economic efficiency of Bactopaslon application on potatoes of Fantasia variety are shown in Table 1.

TABLE 1. The economic efficiency of Bactopaslon application on potatoes (Fantasia variety)

\begin{tabular}{|l|c|c|c|c|}
\hline \multirow{2}{*}{ Index } & \multirow{2}{*}{ Control } & \multirow{2}{*}{ Bactopaslon } & \multicolumn{2}{c|}{$\begin{array}{c}\text { Control } \\
\text { deviation }( \pm)\end{array}$} \\
\cline { 4 - 5 } & & & Absolute & $\%$ \\
\hline Yield, t/ha & 20,35 & 24,55 & $+4,20$ & $+20,6$ \\
\hline $\begin{array}{l}\text { The cost of 1 ha (total cost), } \\
\text { UAH }\end{array}$ & 10892,0 & 11314,0 & $+422,0$ & $+3,9$ \\
\hline $\begin{array}{l}\text { including additional costs for } \\
\text { bacterization UAH/ha }\end{array}$ & - & $+422,0$ & - & - \\
\hline Total cost per 1 t, UAH & 535,2 & 460,9 & $-74,3$ & $-13,9$ \\
\hline Sale price per 1 t, UAH & 850,0 & 850,0 & - & - \\
\hline Sale proceeds per 1 ha, UAH & 17298,0 & 20868,0 & $+3570,0$ & $+20,6$ \\
\hline Profit per 1 ha, UAH & 6406,0 & 9554,0 & $+3148,0$ & $+49,1$ \\
\hline Profit per 1 t, UAH & 314,8 & 389,1 & $+74,3$ & $+23,6$ \\
\hline Profitability, \% & 58,8 & 84,4 & $+25,6$ в.п. & - \\
\hline $\begin{array}{l}\text { Additional expenses } \\
\text { profitability, \% }\end{array}$ & - & 746,0 & - & - \\
\hline
\end{tabular}

Data depicted in the table indicate that the pre-planting potato bacterization promotes a significant increase of economic efficiency. Thus, in variants with Bactopaslon potato yield has increased on 4.20 t/ha or $20.6 \%$, while the costs have increased on only $422.0 \mathrm{UAH} / \mathrm{ha}$ or $3.9 \%$. As a result, the cost has decreased on $74.3 \mathrm{UAH} / \mathrm{t}$ or $13.9 \%$, while the amount of revenue per hectare has increased on $3570.0 \mathrm{UAH} / \mathrm{ha}$ or $20.6 \%$.

The combined effects of these factors contributes to a significant increase of production profitability. Thus, application of Bactopaslon has promoted profitability increase to even greater extent: the amount of profit per hectare has increased on $3148.0 \mathrm{UAH} / \mathrm{ha}$ or $49.1 \%$ while profitability has increased on $25.6 \%$.

The data obtained shows that bacterization of planting material with given microbial preparation significantly increase economic efficiency of potato production.

It should be emphasized that the increase in productivity and improvement of economic efficiency was obtained without the use of fertilizers and substantial additional costs on resources, which is especially important today, at growing costs of resources and crisis conditions when commodity producer is not capable to introduce innovations requiring significant capital investment. 
Based on the performed studies of the economic effectiveness of Bactopaslon for growing potatoes, two main factors with a direct influence (first order factors) on the entire chain of economic indicators can be distinguished: the productivity level and the amount of the costs associated with bacterization of planting material per 1.0 ha. In this connection, it is useful to determine the quantitative impact of these factors on main indices of economic efficiency of potato production: cost of 1 ton of product, the amount of profit per 1 ton of product and 1,0 ha of planting and production profitability. For this purpose deterministic factor analysis was used.

It was established that increase of direct and overhead costs associated with the use of microbial preparation per 1 ha of planting has a slight effect on cost of 1 ton of potatoes $-20.8 \mathrm{UAH} / \mathrm{t}$ (Table 2), but due to the yield increase the production cost has significantly dropped - on 95.1 UAH/t, ensuring its total decrease on $74.3 \mathrm{UAH} / \mathrm{t}$.

The quantitative effect of the studied factors (yield and costs per 1 ha of planting) on profit deviation per 1 ton of potatoes will be the same as on cost deviation of 1 ton of potatoes (but with the opposite sign): $+95.1 \mathrm{UAH} / \mathrm{t}$ and $20.8 \mathrm{UAH} / \mathrm{t}$, correspondingly, resulting in total $+74.3 \mathrm{UAH} / \mathrm{t}$.

TABLE 2. Effect of the cost per 1 hectare and yield on the cost of 1 ton of potato (Fantasia variety) at Bactopaslon application

\begin{tabular}{|l|c|c|}
\hline \multicolumn{1}{|c|}{ Index } & $\begin{array}{c}\text { Legend and } \\
\text { formulas }\end{array}$ & Values \\
\hline Yield (control), t/ha & Ук & 20,35 \\
\hline Yield (experiment), t/ha & Уд & 24,55 \\
\hline Costs per 1 ha (control), UAH & Вк & 10892,0 \\
\hline Costs per 1 ha (experiment), UAH & Вд & 11314,0 \\
\hline Full costs of 1 t (control), UAH & Ск $=\frac{\text { Вк }}{У_{\kappa}}$ & 535,20 \\
\hline Full costs per 1 t (experiment),UAH & Сд $=\frac{\text { Вд }}{У_{д}}$ & 460,90 \\
\hline Estimated (conditional) cost per 1 t, UAH & Су $=\frac{\text { Вд }}{У_{к}}$ & 556,00 \\
\hline Total cost deviation, UAH/t & $\Delta$ Сзаг. $=$ Сд - & $-74,30$ \\
\hline $\begin{array}{l}\text { Cost deviation due to the cost changes per } \\
1 \text { ha, UAH/t }\end{array}$ & $\Delta$ Св $=$ Су - Ск & $+20,80$ \\
\hline $\begin{array}{l}\text { Cost deviation due to the yield changes, } \\
\text { UAH/t }\end{array}$ & $\Delta$ Су $=$ Сд - Су & $-95,10$ \\
\hline
\end{tabular}

According to Table 3, it can be concluded that increase of potato yield profits per 1 ha of planting make $3570.0 \mathrm{UAH}$

At the same time, due to the associated increase of monetary costs per 1 ha of planting area profitability has decreased on $422.0 \mathrm{UAH} / \mathrm{ha}$. Thus, productivity 
increasy has played an essential role, not only increasing the costs but ensuring the overall profit growth on $3148.0 \mathrm{UAH} / \mathrm{ha}$.

TABLE 3. Effect of the cost per 1 hectare and yield on the profit deviation per 1 ha of potato planting (Fantasy variety) at Bactopaslon application

\begin{tabular}{|c|c|c|}
\hline Index & Legend and formulas & Values \\
\hline Yield (control), $\mathrm{t} / \mathrm{ha}$ & Ук & 20,35 \\
\hline Yield (experiment), $\mathrm{t} / \mathrm{ha}$ & Уд & 24,55 \\
\hline Costs per 1 ha (control), UAH & Вк & 10892,0 \\
\hline Costs per 1 ha (experiment), UAH & Вд & 11314,0 \\
\hline Sale price per $1 \mathrm{t}$ of potatoes, UAH & Ц & 850,0 \\
\hline Profit per 1 ha (control), UAH & Пга к $=$ Ц $\times$ Ук - Вк & 6406,0 \\
\hline Profit per 1 ha (experiment), UAH & 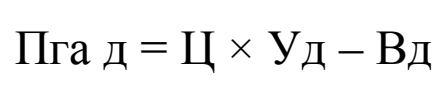 & 9554,0 \\
\hline Estimated profit per 1 ha, UAH & Пга у $=$ Ц $\times \mathrm{У}_{д}-$ Вк & 9976,0 \\
\hline Total profit deviation, UAH/ha & $\begin{array}{c}\Delta \text { Пга заг }=\text { Пга д - } \\
- \text { Пга к }\end{array}$ & $+3148,0$ \\
\hline $\begin{array}{l}\text { Profit deviations due to the yield changes, } \\
\text { UAH / ha }\end{array}$ & $\begin{array}{c}\Delta \text { Пга у }=\text { Пга у- } \\
- \text { Пга к }\end{array}$ & $+3570,0$ \\
\hline $\begin{array}{l}\text { Cost deviation due to the cost changes per } \\
1 \text { ha, UAH/t }\end{array}$ & $\begin{array}{c}\Delta \text { Пга в }=\text { Пга д - } \\
- \text { Пга у }\end{array}$ & $-422,0$ \\
\hline
\end{tabular}

Influence estimation of studied factors on the increase of overall profitability of potato production is shown in Table 4.

The results obtained by factor data analysis have shown that improvement of economic efficiency of potato bacterization with Bactopaslon, observed in all quality parameters is achieved due to a strong positive impact on productivity in comparison with the growth of direct and overhead costs related to the use of given microbial preparation. Therefore, the effects of its use tenfold compensate additional costs associated with Bactopaslon application.

Special attention should be given to the efficiency of microbial preparation as specified innovative method unlike many other innovations, does not require large capital investments which is particularly important in the current economic conditions in Ukraine. 
TABLE 4. Effect of yield and expenditures changes per 1 ha on deviation of profitability of potato (Fantasia variety) at application of Bactopaslon

\begin{tabular}{|c|c|c|}
\hline Index & Legend and formulas & Values \\
\hline Yield (control), $\mathrm{t} / \mathrm{ha}$ & Ук & 20,35 \\
\hline Yield (experiment), $\mathrm{t} / \mathrm{ha}$ & Уд & 24,55 \\
\hline Costs per 1 ha (control), UAH & Вк & 10892,0 \\
\hline Costs per 1 ha (experiment), UAH & Вд & 11314,0 \\
\hline Sale price per $1 \mathrm{t}$ of potatoes, UAH & Ц & 850,0 \\
\hline Profitability per 1 ha (control), UAH & РК $=\left(\frac{Ц \times У_{\kappa}}{\text { ВК }}-1\right) \times 100 \%$ & 58,8 \\
\hline Profitability per 1 ha (experiment), UAH & Рд $=\left(\frac{Ц \times У_{д}}{\mathrm{Bд}}-1\right) \times 100 \%$ & 84,4 \\
\hline Expected profitability level, $\%$ & $\mathrm{Pp}=\left(\frac{Ц \times \mathrm{У}_{\text {д }}}{\mathrm{B \kappa}}-1\right) \times 100 \%$ & 91,6 \\
\hline $\begin{array}{l}\text { General deviation of profitability level, } \\
\text { r.i. }\end{array}$ & $\Delta \mathrm{P}_{3 а \Gamma}=$ Рд - Рк & $+25,6$ \\
\hline $\begin{array}{l}\text { Deviation of profitability due to the yield } \\
\text { changes, r. i. }\end{array}$ & $\Delta \mathrm{Py}=\mathrm{Pp}-\mathrm{P \kappa}$ & $+32,8$ \\
\hline $\begin{array}{l}\text { Deviation of profitability due to the costs } \\
\text { changes per } 1 \text { ha, r. i. }\end{array}$ & $\Delta \mathrm{PB}=\mathrm{Pд}-\mathrm{Pp}$ & $-7,2$ \\
\hline
\end{tabular}

In this regard, the assessment of energy efficiency of microbial preparation use looks reasonable, including yield cost recovery of human energy. In contrast to the economic evaluation undertaken in value terms, subject to the influence of market conditions, prices disparity and inflationary process, etc., energy evaluation provides an objective overview of the effectiveness and appropriateness of studied agricultural technique as well as effectiveness of corresponding agro-ecosystem as a whole.

For this purpose, the calculations of energy assessment under the use of Bactopaslon for potatoes growing were performed. At this, production operations and resources costs (used for the economic evaluation) were converted in the relevant energy equivalents $[6,7]$.

The analysis of main energy efficiency indices of potato of Fantasia variety in control and experimental variants (Table 5) have shown the high energy efficiency of bacteryzation of planting material for growing potatoes.

Thus, the energy efficiency ratio (the ratio of total energy of major and minor products to the cost of human energy) in control was 3.98, while at application of Bactopaslon -4.39 . At this, the energy efficiency ratio for additional costs (the ratio of additional energy yield obtained with bacteryzation means, to extra cost of human energy associated with its use) was 9.38 . 
TABLE 5. Energy efficiency of Bactopaslon in growing potato (Fantasia variety)

\begin{tabular}{|l|c|c|}
\hline \multirow{2}{*}{\multicolumn{1}{|c|}{ Index }} & \multicolumn{2}{c|}{ Energy efficiency, MJ } \\
\cline { 2 - 3 } & Control & Bactopaslon \\
\hline Energy-output ratio - total & 28698,0 & 31058,0 \\
\hline Including: - labor inputs & 421,0 & 484,0 \\
\hline - tractor and motor vehicles & 1478,0 & 1655,0 \\
\hline - agricultural tools & 4532,0 & 5478,0 \\
\hline - diesel fuel & 2214,0 & 2214,0 \\
\hline - gasoline & 4528,0 & 5412,0 \\
\hline - electricity & 84,0 & 170,0 \\
\hline - manufacture costs of microbial preparation & - & 205,0 \\
\hline - protection means & 520,0 & 520,0 \\
\hline - planting material & 14921,0 & 14921,0 \\
\hline Additional energy costs (to control) & - & 2360,0 \\
\hline Yield energy content - total & 114216,0 & 136342,0 \\
\hline Including: - major product & 70614,0 & 85189,0 \\
\hline - minor product & 43602,0 & 51153,0 \\
\hline Energy content of additional yield (to control) & - & 22126,0 \\
\hline Energy efficiency ratio & 3,98 & 4,39 \\
\hline $\begin{array}{l}\text { Energy efficiency ratio for additional energy } \\
\text { expenditures }\end{array}$ & - & 9,38 \\
\hline
\end{tabular}

Summing up the analysis results of the economic and energy efficiency technologies at Bactopaslon application on potato of Fantasia variety it can be concluded that given preparation is highly effective both in economic and in energy terms. 